\title{
Establishment of chromium detecting kit and its application in sea water and seafood
}

\author{
Cuijuan Shi ${ }^{1}$, Xiujun Gao ${ }^{1}$, Qiuju Xie ${ }^{1}$, and Guangfeng Kan ${ }^{1 *}$ \\ ${ }^{1}$ Harbin Institute of Technology at Weihai, College of Marine Science and Technology, 264209 Weihai, PR China
}

\begin{abstract}
Chromium is one of main pollution in sea water, and the establishment of detecting kit is the research hot topic. In this study, immunized mice were obtained by immunogen $\mathrm{Cr}^{3+}$-EDTA-BSA, and hybridoma strains that secrete $\mathrm{Cr}^{3+}$-EDTA monoclonal antibody were selected. $\mathrm{Cr}^{3+}$-EDTA mAb were prepared with in vivo method. Then, Cr-kit for measurement of chromium was developed, and its application was executed in sea water and seafood. Two hybridoma strains of A321 and A424 were screened. The Cr-kit standard curve of the linear range was $1.0-512 \mu \mathrm{g} / \mathrm{L}$, and limit of detection was $1.0 \mu \mathrm{g} / \mathrm{L}$. The average recovery rates $\mathrm{Cr}$ spiked in samples of sea water, clam and shrimp were $102.62 \%$, $94.69 \%$ and $96.29 \%$, which were accordance with the results of ICP-AES. Totally, Cr-kit was successfully developed and behaved broad application potential in sea water and seafood.
\end{abstract}

\section{Introduction}

With the development of economy, heavy metal pollution is more and more serious in marine environments[1]. Heavy metal pollution not only directly damages the natural environment, but can enrich in organisms through adsorption or ingestion of marine organisms. The enriched metals directly endanger growth and survival of marine organisms, and damages human health by feeding[2,3].

It is difficult to control the marine pollution caused by heavy metals, which can not be decomposed by microorganisms[4]. Therefore, it is a key measure to detect the sea frequently to prevent marine pollution. Now, the chemical analysis methods can detect the heavy metal content in marine environment or organisms, but the results can not reflect the toxic effect of pollutants on organisms [5]. Therefore, it is necessary to establish a convenient, economic and sensitive bioassay method.

The purpose of this study is to prepare $\mathrm{Cr}^{3+}$ monoclonal antibodies, develop chromium detection kit, and provide an effective method for the detection of chromium in seawater and seafood.

\section{Materials and methods}

\subsection{Materials}

Chromium chloride is analytical grade. Freund's complete and incomplete adjuvants are Roche products. Immunogen $\mathrm{Cr}^{3+}$-EDTA BSA and coating antigen $\mathrm{Cr}^{3+}$-EDTA OVA are synthesized by Shanghai Yaoqiang Biotechnology Co., Ltd.

\subsection{Experiment methods}

\subsubsection{Preparation of $\mathrm{Cr}^{3+}-\mathrm{EDTA}$ mAb}

The mice were immunized with the immunogen $\mathrm{Cr}^{3+}$-EDTA BSA, then the blood was collected to separate serum, and the antibody titer was detected. The immune spleen cells and tumor cells were mixed, screened and cloned to determine the monoclonal hybridoma cells and establish the positive hybridoma cell line. The $\mathrm{Cr}^{3+}$-EDTA mAb was prepared by intraperitoneal injection of Freund's incomplete adjuvant and tumor cells. After obvious enlargement in mice abdomen, the ascites were collected and purified by affinity chromatography[6].

\subsubsection{The preparation of Cr-kit}

(1) The optimum concentrations of coating antigen

$\mathrm{Cr}^{3+}$-EDTA OVA, $\mathrm{Cr}^{3+}$-EDTA mAb and RaMIgG-HRP were determinated with chessboard format[2].

(2) Assembly of Cr-kit

Enzyme labeled board was coated with diluted $\mathrm{Cr}^{3+}$-EDTA-OVA with $100 \mu \mathrm{L} /$ well, and then blocked by blocking buffer with $250 \mu \mathrm{L} /$ well. Other reagents include $\mathrm{Cr}^{3+}$-EDTA mAb, RaMIgG-HRP, substrate buffer and stop solution.

(3) Operation procedure of Cr-kit

Firstly, the labeled board was coated with $50 \mu \mathrm{L} /$ well $\mathrm{Cr}^{3+}$-EDTA $\mathrm{mAb}$, incubated at $37{ }^{\circ} \mathrm{C}$ for $20 \mathrm{~min}$, and then washed for 6 times with PBST buffer. Secondly, 50

Responding author: gfkan@hit.edu.cn (Guangfeng Kan) 
$\mu \mathrm{L} /$ well RaMIgG-HRP and $\mathrm{Cr}^{3+}$-EDTA standard samples were separately added, incubated at $37{ }^{\circ} \mathrm{C}$ for $20 \mathrm{~min}$, and then washed for 6 times with PBST buffer. Thirdly, $100 \mu \mathrm{L} /$ well substrate buffer was added and visualization for $5 \mathrm{~min}$ at room temperature. Finally, $100 \mu \mathrm{L} /$ well stop buffer was added and recorded $\mathrm{A}_{450}$ value.

(4) Establishment of standard working curve of Cr-kit

According to the above operation procedure of the Cr-kit, the $\mathrm{A}_{450}$ value of standard solution (B) and blank solution $\left(\mathrm{B}_{0}\right)$ were detected. $\mathrm{B} / \mathrm{B}_{0}$ value was taken as ordinate, and the common logarithm of standard solutions was taken as the abscissa to draw the standard curve.

\section{(5) Sample pretreatment}

For liquid samples such as sea water, $0.1 \mathrm{~mol} / \mathrm{L}$ EDTA was added and mixed. After incubation for $30 \mathrm{~min}$, the mixture was centrifuged for $10 \mathrm{~min}$ at $5000 \mathrm{rpm}$ and $\mathrm{A}_{450}$ of the supernatant was detected. For seafood such as clam and shrimp, $1.0 \mathrm{~g}$ sample was added to flask, and then add $1 \mathrm{ml}$ double-distilled water and $6 \mathrm{ml}$ mixed acid solution ( $3 \mathrm{ml} \mathrm{H}_{3} \mathrm{PO}_{4}$ and $3 \mathrm{~mL} \mathrm{H}_{2} \mathrm{SO}_{4}$ ). The sample was heated to white smoke. After cooling, the flask was added $0.5 \mathrm{ml} \mathrm{HNO}_{3}$, and heated until the sample turns white. The digested sample was transferred into $50 \mathrm{ml}$ centrifuge tube, and centrifuged at $5000 \mathrm{rpm}$ for $10 \mathrm{~min}$. The supernatant was moved into $100 \mathrm{~mL}$ flask, and then added $10 \mathrm{~mL} \mathrm{Na} \mathrm{SO}_{3}(1 \mathrm{~mol} / \mathrm{L}, \mathrm{pH} 9.5)$. After stirring 1 $\mathrm{h}, 10 \mathrm{ml} 0.1 \mathrm{~mol} / \mathrm{L}$ EDTA was added, the sample was obtained with a final volume of $100 \mathrm{ml}$.

\subsubsection{Performance of Cr-kit properties}

\section{(1) Detection limit and stability}

The $\mathrm{IC}_{15}$ value of $\mathrm{Cr}^{3+}$-EDTA was taken as the detection limit[7]. The Cr-kit was stored in a refrigerator at $4{ }^{\circ} \mathrm{C}$. The stability of the kits was determined at 0,30 , $90,180,270$ and 360 days.

(2) Accuracy and precision

The $\mathrm{Cr}^{3+}$-EDTA standard solution was added to seawater, clam and shrimp separately, with the final concentration of $0 \mu \mathrm{g} / \mathrm{L}, 5.0 \mu \mathrm{g} / \mathrm{L}, 10.0 \mu \mathrm{g} / \mathrm{L}$ and 50.0 $\mu \mathrm{g} / \mathrm{L}$ in 3 samples. The accuracy was determined by recovery and standard deviation of 6 paralleled determinations. The $\mathrm{Cr}$-kits were assembled at different time periods, and the precision was determined by intraand inter-assay of standard deviation in 6 paralleled samples.

\subsubsection{Application of the Cr-kit in seawater and seafood}

Three seawater samples, three clams and three shrimps were collected from Weihai, Shandong. The samples blocked with blocking buffer were used as negative control. The $\mathrm{Cr}$ content was detected with $\mathrm{Cr}$-kit and ICP-AES respectively to check the consistency.

\section{Results and analysis}

\subsection{Preparation of $\mathrm{Cr}^{3+}$-EDTA mAb}

The results of cell fusion are shown in Figures 1 and 2. The results showed that four mice behaved high titers, of which M2 manifested the highest titer value of 1:(4.98 $\left.\times 10^{4}\right)$ and the lowest $\mathrm{IC}_{50}$. Therefore, M2 was selected for cell fusion.

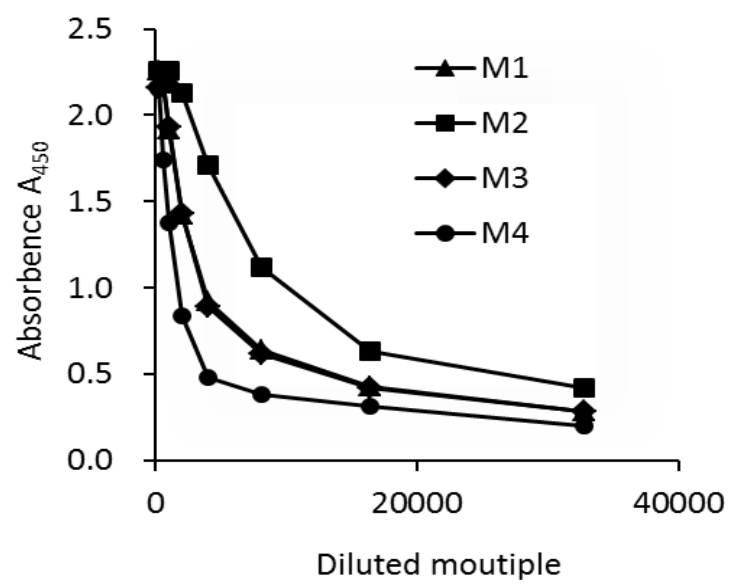

Fig.1. Titer detection of the supernatant antibodies

The screening results of hybridoma cell lines showed the positive rate of the fused cells was $100 \%$ after three cloning. According to the determined results of titer and $\mathrm{IC}_{50}$, two hybridoma cell lines A321 and A424 with high efficiency and high sensitivity were screened.

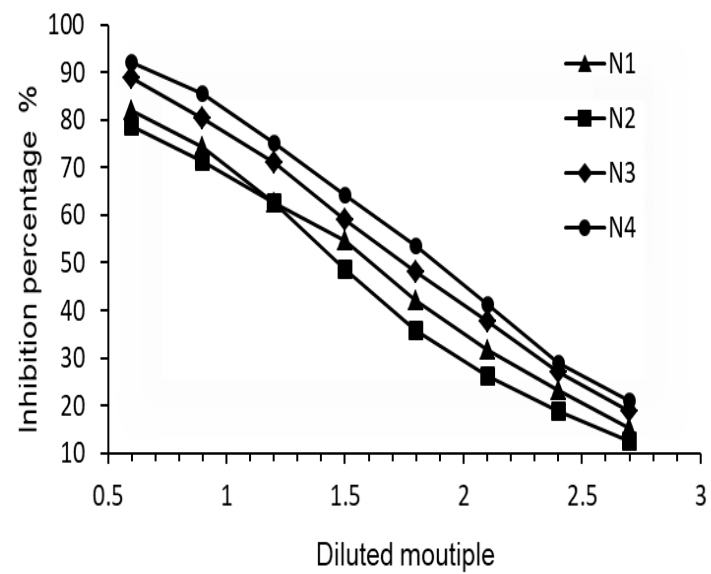

Fig. 2. Inhibitory curves of supernatant antibodies against $\mathrm{Cr}^{3+}$-EDTA

\subsection{Development of Cr-kit}

The best working concentrations of $\mathrm{Cr}^{3+}$-EDTA-OVA, $\mathrm{Cr}^{3+}$-EDTA-mAb and RaMIgG-HRP were $2.2 \mu \mathrm{g} / \mathrm{mL}, 1$ : $\left(4.98 \times 10^{5}\right)$ and $1:\left(10^{3}\right)$ respectively. The standard curve of Cr-kit was shown in Figure 3. The curvilinear regression equation was $\mathrm{y}=-34.463 \mathrm{x}+101.3, \mathrm{R}^{2}=$ 0.9933, $\mathrm{IC}_{50}=28.29 \mu \mathrm{g} / \mathrm{L}$, and the linear range was 
$1.0-512 \mu \mathrm{g} / \mathrm{L}$.

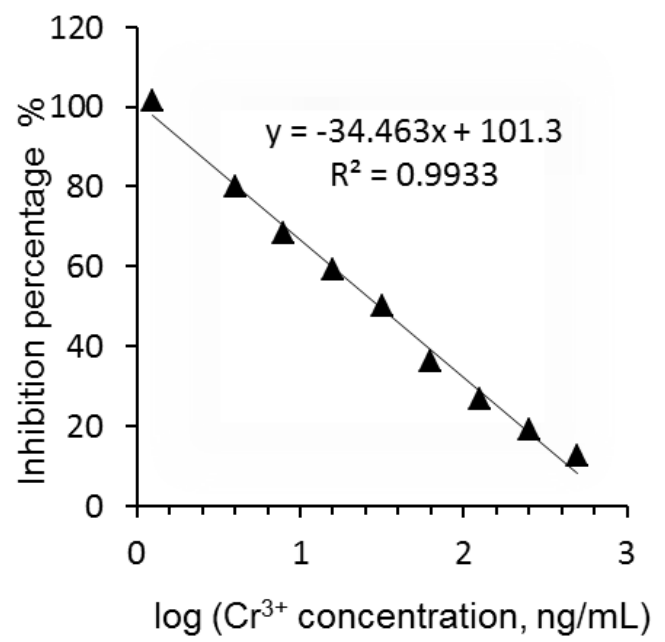

Fig. 3. Calibration curve of ELISA kit

\subsection{Performance test of Cr-kit}

\subsubsection{Detection limit and stability determination}

The $\mathrm{IC}_{15}$ of Cr-kit of $\mathrm{Cr}^{3+}$-EDTA was $0.9 \mu \mathrm{g} / \mathrm{L}$, and the detection limit is defined as $1.0 \mu \mathrm{g} / \mathrm{L}$ due to the existence of error.

The stability test result was shown in Table 1. During the storage period of 270 days, the detection limit, linear range, $\mathrm{IC}_{50}$ and $\mathrm{R}^{2}$ had no significant changes. However, the decrease of absorbance and the increase of IC50 were significant at 360 days. Therefore, the shelf life of the Cr-kit was 270 days.

Table 1. The stability detection of Cr-Kit

\begin{tabular}{cccc}
\hline Conservation time $/ \mathrm{d}$ & $\mathrm{IC}_{50} /(\mu \mathrm{g} / \mathrm{L})$ & $\mathrm{R}^{2}$ & $\mathrm{~A}_{\max }$ \\
\hline 0 & 8.45 & 0.9799 & 0.993 \\
30 & 8.50 & 0.9816 & 0.987 \\
90 & 8.58 & 0.9836 & 0.935 \\
180 & 8.65 & 0.9798 & 0.875 \\
270 & 8.73 & 0.9872 & 0.856 \\
360 & 10.29 & 0.9259 & 0.612 \\
\hline
\end{tabular}

\subsubsection{Determination of accuracy and precision}

The results of the accuracy and precision determination are shown in Table 2. For seawater sample, the recovery rate was $99.76 \%-105.3 \%$ with an average of $102.6 \%$, and RSD was $8.9 \%-13.5 \%$ with an average of $10.3 \%$. For clam samples, the recovery rate was $99.7 \%-104.6 \%$ with an average of $101.8 \%$, and RSD was $6.3 \%-12.3 \%$ with an average of $9.5 \%$. For shrimp samples, the recovery rate was $92.6 \%-98.6 \%$ with an average of $96.3 \%$, and RSD was $8.6 \%-10.9 \%$ with an average of $9.5 \%$. The results showed that four treatments were significantly different among different samples $(\mathrm{P}<0.05)$, and RSD was relatively stable with no significant difference $(\mathrm{P}>0.05)$. The results showed $\mathrm{Cr}$-kit was fit for the determination of total chromium residue.

Table 2. The accuracy and precision detection of $\mathrm{Cr}-\mathrm{Kit}$

\begin{tabular}{ccccc}
\hline Sample & $\begin{array}{c}\mathrm{Cr}^{3+} \text {-EDTA concentration } \\
(\mu \mathrm{g} / \mathrm{L})\end{array}$ & $\begin{array}{c}\text { Detection value } \\
(\mu \mathrm{g} / \mathrm{L})\end{array}$ & $\begin{array}{c}\text { Recovery } \\
(\%)\end{array}$ & $\begin{array}{c}\text { RSD } \\
(\%)\end{array}$ \\
\hline Sea water & 0 & $0.083 \pm 0.04 \mathrm{a}$ & - & 9.6 \\
& 5 & $5.14 \pm 0.23 \mathrm{~b}$ & 102.8 & 13.5 \\
& 10 & $10.53 \pm 0.87 \mathrm{c}$ & 105.3 & 8.9 \\
& 50 & $49.88 \pm 2.12 \mathrm{~d}$ & 99.76 & 9.3 \\
Clam & 0 & $0.12 \pm 0.03 \mathrm{a}$ & - & 10.6 \\
& 5 & $4.73 \pm 0.31 \mathrm{~b}$ & 94.6 & 12.3 \\
& 10 & $9.28 \pm 0.79 \mathrm{c}$ & 92.8 & 8.7 \\
Shrimp & 50 & $48.33 \pm 3.06 \mathrm{~d}$ & 96.66 & 6.3 \\
& 0 & $0.13 \pm 0.05 \mathrm{a}$ & - & 10.9 \\
& 5 & $4.93 \pm 0.21 \mathrm{~b}$ & 98.6 & 8.6 \\
& 10 & $9.26 \pm 0.32 \mathrm{c}$ & 92.6 & 9.5 \\
\hline
\end{tabular}

Note: Different lowercase letters in the same column indicate significant difference $(\mathrm{p}<0.05)$.

\subsubsection{Effect of $\mathrm{pH}$ to $\mathrm{Cr}-\mathrm{kit}$}

The effect of $\mathrm{pH}$ on the kit was shown in Figure 4. The results showed that $\mathrm{pH}$ influenced the Cr-kit greatly. When $\mathrm{pH}<7.0, \mathrm{~B}_{0}$ and $\mathrm{IC}_{50}$ increased significantly, which affected the sensitivity of Cr-kit. When $\mathrm{pH}>8.5, \mathrm{~B}_{0}$ and $\mathrm{IC}_{50}$ increased slightly and affected the accuracy of Cr-kit. Therefore, $\mathrm{pH} 7.0-8.5$ is the optimum reaction condition. 


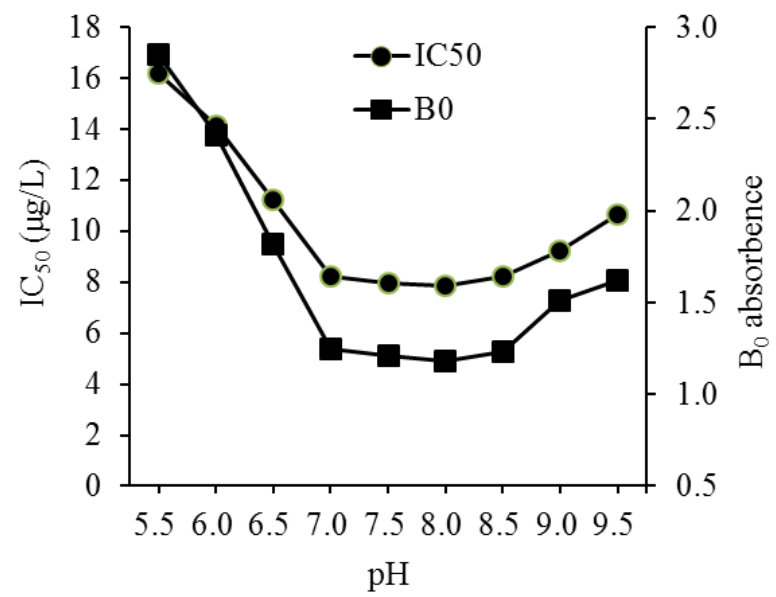

Fig.4. Effect of $\mathrm{pH}$ in sample matrix on $\mathrm{B}_{0}$ value and $\mathrm{IC}_{50}$ value

\subsection{Application of Cr-kit in sea water and seafood}

Table 3 showed the detection results of $\mathrm{Cr}$ concentration in sea water and seafood. The data indicated the detection results of Cr-kit and ICP-AES were basically the same, and RSD was relatively stable.

In this study, the $\mathrm{Cr}$ concentration in Weihai sea area was about $1.0-3.1 \mu \mathrm{g} / \mathrm{kg}$ and higher than that of $0.3-0.47 \mu \mathrm{g} / \mathrm{kg}$ in Longdao sea area of Tangshan City, Hebei Province[8]. In clam and shrimp, the $\mathrm{Cr}$ concentration was about $0.08-2.12 \mu \mathrm{g} / \mathrm{kg}$ and lower further than that of $2.0 \mathrm{mg} / \mathrm{kg}$ in Shaoxing City seafood market[9].

Table 3. The Cr concentration detection of sea water and seafood

\begin{tabular}{cccc}
\hline Sample & No. & Cr-Kit $(\mu \mathrm{g} / \mathrm{kg})$ & ICP-AES $(\mu \mathrm{g} / \mathrm{kg})$ \\
\hline Sea water & SW1 & $2.18 \pm 0.068$ & $2.17 \pm 0.033$ \\
& SW2 & $3.06 \pm 0.032$ & $3.11 \pm 0.018$ \\
& SW3 & $1.02 \pm 0.073$ & $1.06 \pm 0.024$ \\
Clam & CL1 & $1.89 \pm 0.12$ & $1.92 \pm 0.081$ \\
& CL2 & $1.35 \pm 0.066$ & $1.2 \pm 0.018$ \\
& CL3 & $1.22 \pm 0.038$ & $1.35 \pm 0.043$ \\
Shrimp & SH1 & $0.084 \pm 0.006$ & $0.086 \pm 0.005$ \\
& SH2 & $1.22 \pm 0.054$ & $1.25 \pm 0.048$ \\
& SH3 & $2.12 \pm 0.069$ & $2.2 \pm 0.055$ \\
\hline
\end{tabular}

\section{Conclusion}

The quality, performance and detection limit of Cr-kit depend on the affinity of the antibody[10]. In this study, a detection method for heavy metal chromium was established by high affinity antibody. The detection limit of Cr-kit was $1 \mu \mathrm{g} / \mathrm{L}$, and the detection range was $1.0-512 \mu \mathrm{g} / \mathrm{L}$. The accuracy of standard curve is determined by the setting of the standard point. In this study, the standard point was set as $\mathrm{IC}_{15}$, which was on the same curve with the content of $\mathrm{Cr}^{3+}$-EDTA. Additionally, through the recovery test and practical application, the standard point behaved good linear relationship, high sensitivity and accuracy.
In this study, $\mathrm{Cr}^{3+}$-EDTA mAb with high titer, high affinity and strong specificity was prepared by cell fusion technology. Cr-kit for total chromium contamination in sea water and seafood was successfully developed. The kit behaved the advantages of low detection limit, good accuracy and strong specificity, and showed broad prospects and application value.

\section{Acknowledgement}

This work was supported by Key Technologies R \& D Program of Shandong (2019GHY112047).

\section{References}

1. S. Zhan, S. Peng, C. Liu, Q. Chang, J. Xu, B. Environ. Contam. Tox., 84, 6 (2010)

2. X. Zhang, X. Wang, M. Sun, X. Zhang, H. Song, Y. Yan, J. Sun, X. Li, W. Fang, Toxins, 7, 6 (2015)

3. K. Rehman, F. Fatima, I. Waheed, M.S.H. Akash, J Cell Biochem., 119, 8 (2018)

4. X. Hu, X. Liu, L. Qiao, S. Zhang, K. Su, Z. Qiu, X. Li, Q. Zhao, C. Yu, Sci. Total Environ., 775, 12 (2021)

5. Y. Guo, J. Li, J. Liu, T. Wang, Y. Li, Y. Yuan, J. Zhao, D. Chang, X. Fang, T. Li, J. Wang, W. Dai, C. Fang, C. Liu, Arch. Med. Res., 46, 10 (2015)

6. S. Ling, S. Xiao, C. Xie, R. Wang, L. Zeng, K. Wang, D. Zhang, X. Li, S. Wang, Toxins, 10, 11 (2018)

7. J. Wang, W. Sheng, J.P. Wang, Food and machinery, 28, 3(2012). (in Chinese with English abstract)

8. W. Fan, J. Wang, L. Chen, Environ. Occup. Med., 33, 5 (2016), (in Chinese with English abstract)

9. B. Han, F.X. Lin, Y. Ding, J.X. Li, L. Zheng, Marine Environmental Science, 38, 7 (2019)

10. I. Krämer, J. Thiesen, A. Astier, Pharm. Res., 37, 18 (2020) 